\title{
Pending Section 232 Litigation and Broader Trade Trends: Will the US Courts Restrict Presidential Authority from Relying upon "National Security"?
}

Stuart S. Malawer**

This article discusses American Institute for International Steel v. the United States, which is pending in the little-known United States Court of International Trade in New York. It involves an attempt to declare that the US legislation delegating authority to the president to impose trade restrictions is an unconstitutional delegation of legislative authority. A loss would legally curtail the president's discretionary power to use national security as a reason to impose punitive measures against trading partners. The article identifies legal trends, where this case fits into the trade policy debates, and why it is so important. The article concludes that domestic US litigation in 2019 may well have a tremendous impact on US law and the global trading system. Many in the domestic and international trading communities (as well as those in the foreign policy and national security communities) are waiting for the results of this little-known steel litigation.

Keywords: Section 232, National Security, AIIS v. the United States, US Court of International Trade, Huawei, Extraterritoriality, Commercial Espionage

* Distinguished Service Professor of Law and International Trade at George Mason University's Schar School of Policy and Government. J.D. (Cornell), M.A./Ph.D.(UPenn), Diploma (Hague Academy of International Law: Research Centre). Additional legal studies at the Harvard Law School and Oxford University (St. Peter's College). ORCID: http://orcid.org/0000-0003-13045710. He is a former member of the board of directors of the Virginia Economic Development Partnership and a recent Virginia gubernatorial appointee to its new Committee on International Trade. The author may be contacted at: StuartMalawer@msn.com; http://www. GlobalTradeRelations.net/Address: 3351 Fairfax Dr., MS 3B1, Arlington, Virginia 22201 USA. 


\section{Introduction}

A number of new legal trends are only now emerging in President Trump's trade policies. A little-known federal court case brought by steel importers ${ }^{1}$ might result in a historic defeat for the administration because it attempts to rely on national security as a basis for broad tariffs on China and other countries.

This domestic US case complements the onslaught of litigation within the World Trade Organization ("WTO") contesting the international legality of President Trump's tariffs that rely upon national security under Section 232. Separate actions have been brought by $\mathrm{China}^{2}$ and the EU. ${ }^{3}$ They have been joined by 29 countries as third-party complainants. A total of nine separate cases have been filed in the WTO against the US for its abusive reliance upon Section $232{ }^{4}$

This article discusses American Institute for International Steel v. the United States, which is pending in the little-known United States Court of International Trade in New York, where a motion for summary judgment was recently heard on December 19, 2018. ${ }^{5}$ It involves an attempt to declare that the legislation delegating authority to the president to impose trade restrictions is an unconstitutional delegation of legislative authority to the president by Congress. One commentator stated: "The lawsuit is a direct challenge to a cornerstone of Mr. Trump's trade policies [...] A decision on the suit isn't expected until 2019 and could take months. A loss would legally curtail the president's discretionary power to use national security as a reason to impose punitive measures against a trading partner."

\section{Broader Legal Trends and Trade Policies}

First, I want to identify legal trends, where this case fits into the trade policy debates, and why it is so important. One trend now coming into focus is that President Trump is attempting to weaponize various pieces of the US economic legislation, and he has mobilized the US Department of Justice to aid in his trade war with China. This amounts to an expansive application of laws that govern the American participation in global trade. This growing cross section of the federal 
criminal law and trade relations is highly unusual and troubling in the US.

A second trend, of which the use of federal criminal law is only a subset, is the aggressive extraterritorial application of the US international economic legislation by the Trump administration. For example, this includes the Trump administration's series of criminal actions against Chinese nationals for commercial economic espionage. ${ }^{7}$ This also includes the extraterritorial application of sanction legislation, export controls, and their interplay with extradition treaties. ${ }^{8}$ This aggressive use of economic legislation is based on the long-standing extraterritorial application of antitrust and securities legislation. Most recently, new anti-terrorist legislation amending the foreign sovereign immunities legislation has been adopted and applied extraterritorially by the US courts.

The "judicial presumption of territoriality" in the US is intended to limit the application of the US law to the US unless Congress intends otherwise. However, this limit is overcome when courts determine that foreign actions could reasonably have domestic effects within the US. This, of course, is based on the 1927 Permanent Court of International Justice's decision in the Lotus case. ${ }^{10}$ Now, however, the Trump administration has dramatically expanded the notion of extraterritoriality as part of its trade and tariff wars.

Consider the recent US request for the extradition of Huawei's chief financial officer, Ms. Meng, from Canada. THe New York Times reports: "Law enforcement officials say they worry that Mr. Trump is inflaming the perception among foreign critics that the United States' sanction-related or extradition cases are expedient tools for achieving unrelated goals, not an exercise in the rule of law." 11

The US requested extradition for alleged violations of the US sanctions legislation by a Chinese telecom company involving a foreign subsidiary, a foreign bank, and sales to Iran. This is highly unusual as such prosecutions are against the foreign corporation, not a corporate officer. This case illustrates the politicization of an extradition treaty. Most extradition treaties are not applicable when criminal prosecutions are utilized for political purposes. Extradition treaties often make an exception for crimes of a 'political character.' International political economist Jeffrey Sachs stated: "The unprecedented arrest of Ms. Meng is even more provocative because it is based on US extraterritorial sanctions 
- that is, the claim by the US that it can order other countries to stop trading with third-party countries such as Cuba or Iran." ${ }^{, 12}$ As a recent editorial in THE Financial Times concluded, "Presidential interference in Ms Meng's case would send a worse signal: that rule of law in the US is a function of the whim of the chief executive, or that illegal behavior can be up for negotiation." ${ }^{, 13}$

The Huawei case glaringly demonstrates the Trump administration's use of domestic legislation (and criminal laws in particular) to threaten foreign governments for trade or political purposes. It is a grossly abusive application of the US legislation intended to win a unilateral political advantage. This contradicts the legislation's original intention, which is to promote free global commerce and to protect the US national interests.

The use of such threats and duress violates customary international law that prohibits the threat or use of force as a means in international relations ${ }^{14}$ and declares void all international agreements that are procured by such duress. ${ }^{15}$

The above actions represent the Trump administration's reliance on economic legislation involving the delegation of congressional authority to the president. Congress, not the president, has the exclusive authority under the commerce clause of Article 1, Section 8, clause 3 of the US Constitution to regulate interstate and foreign commerce. Congress also has the exclusive power to tax under Article 1, Section 8, clause 1 and of course tariffs are taxes. The power to regulate trade is unlike foreign affairs where the president has broad authority, but that authority is still shared with Congress. Nevertheless, even the power to declare war, an exclusive congressional power, has often been encroached upon by the Executive Branch. ${ }^{16}$

\section{Pending Action in the US Court of International Trade}

Today, the US Court of International Trade is being asked to weigh in on one particular statute concerning trade and national security. This request is based on the mostly dormant "non-delegation doctrine" and confronts a president who takes unprecedented actions. This court (formerly known as the Customs Court) is a federal court in New York City with jurisdiction over trade-related cases. Under expedited procedures, decisions may be reviewed directly by the US 
Supreme Court. ${ }^{17}$

The American Institute for International Steel filed its case against the Trump administration in June of 2018. A motion for summary judgment was heard on December 19, 2018 before a three-judge panel that could lead to an expedited Supreme Court hearing sometime in 2019.

The case involves a broadside by steel importers against the administration's use of national security as a basis for imposing tariffs on steel and aluminum imports. It claims that Congress failed to define 'national security' or establish a sufficient criteria for applying that term. This authority to adjust imports or to impose other trade restrictions in cases involving threats to national security was initially delegated to the president by Congress under Section 232(b) of the Trade Expansion Act of 1962. A continuous congressional practice to delegate authority to the president in trade has existed since the Roosevelt administration in the 1930s, and a number of proceedings have been held over the years. Specifically, this includes 26 Section 232 investigations that resulted in nine affirmative determinations by the US Department of Commerce. The president imposed a trade action in six of those cases. ${ }^{18}$ However, such cases never resulted in tariffs as broadly based as those imposed by President Trump. Very simply, the issue in this case is whether this delegation of authority as exercised by President Trump is unconstitutional. ${ }^{19}$

The plaintiffs argue the legislation was so vague that it amounted to the delegation of legislative authority to the president. They further argue that the delegation of authority violated a basic tenet of the separation of powers established by the US Constitution as discussed by the Supreme Court in the Curtiss-Wright case of $1936 .^{20}$ If this argument is upheld by the US Court of International Trade and the Supreme Court, it would be a historic decision. This would severely hamper the president in his use of other statutes impacting trade. Most importantly, however, such a decision would put a more general brake on the president's glaring abuse of many legal rules and norms in international trade and relations.

The following are among the most important court precedents pertaining to this pending case. The Supreme Court in the Youngstown case of 1952 held that the commander in chief's powers do not include the power to regulate domestic commerce on the basis that it may impact foreign military actions. ${ }^{21}$ 
That case involved the president's seizure of steel mills during the Korean War. The Algonquin case of 1976 upheld President Nixon's action to require an oil license fee under Section 232 rather than to require a quota. ${ }^{22}$ However, the court declared that this was a very limited decision, and it was an issue of whether license fees could be used in addition to quotas. The Yoshida case of $1974,{ }^{23}$ interpreting Section 5(b) of the Trading with the Enemy Act, held that President Nixon acted within his delegated authority when, after declaring a 'national emergency,' he imposed tariff surcharges. This case involved zippers.

None of these cases dealt with the specific issue of the unconstitutional delegation of the legislative authority to impose broad tariff restrictions. They clearly do not support the argument that the "non-delegation doctrine" is dead. Nor do they support the argument that the claims of 'national security' are not judicially reviewable. The recent string of immigration decisions by the federal courts make this abundantly clear. Thus, the decision the US Court of International Trade faces is one of the most consequential decisions it has ever had to make.

It is important to note that during the oral argument for summary judgment, one judge asked whether peanut butter would be a matter of national security. ${ }^{24}$ I suggest that she could have expanded the question of whether zippers are a matter of national emergency.

Congress is likely to consider legislation limiting Trump's hardline trade actions. As the well-known conservative columnist George Will recently stated: "There is growing legislative resistance to some broad powers that presidents possess because legislators improvidently - and arguably, unconstitutionally - delegated them to presidents, particularly regarding international trade." ${ }^{25}$ Increasingly, some Republicans intend to limit Trump's trade authority. ${ }^{26}$

President Trump recently declared a 'national emergency' under the National Emergencies Act and related legislation to build a border wall along the Mexican border. This outrageous pronouncement glaringly highlights the expansive interpretations the Trump administration is giving to national security, national emergency and related legislation. Thus, the decision the US Court of International Trade faces in this steel case is one of the most consequential decisions it has ever had to make. 


\section{Conclusion}

Here are 10 observations:

1. The current case by steel importers pending before the Court of International Trade is truly consequential. It attacks significant congressional legislation as unconstitutional based on the principle that Congress cannot delegate away its legislative function to regulate foreign commerce. This legislative responsibility is a cornerstone of the separation of powers. Such attacks are rare, and courts have not comprehensively addressed this principle in terms of trade issues. This case has important foreign policy and national security implications because Congress has exclusive authority over trade, and many international political and diplomatic issues today concern trade.

2. This pending steel case in the Court of International Trade illustrates administration's action in the context of its overly extensive extraterritorial application of other US international economic legislation for political ends. This is particularly the situation in confronting violations of the US sanctions and export controls. Such extraterritoriality is increasingly relevant concerning China's commercial espionage. $^{27}$

3. I have written previously about China's commercial espionage. My conclusion is that a better policy for the US in applying its criminal laws extraterritorially would be to bring the WTO action against China under the TRIPS agreement. This would avoid the stigma of unilateral actions. ${ }^{28}$ The filing of an action by the US against China last March concerning intellectual property rights ${ }^{29}$ is a good beginning, but it does not reach the issue of commercial espionage.

4. This steel case before the US Court of International Trade today addresses only one aspect of President Trump's attack on the rule of law. Other areas include withdrawing from international agreements and multilateral institutions. A conservative foreign policy expert recently stated: “Trump's statements and actions are driving a stake through it [the liberal world order].",30

5. The president's trade actions are more frequently accompanied by the use of criminal law, by the US Department of Justice, and by the abuse of extradition treaties to secure political objectives rather than criminal ones. A recent news account stated: "To combat Chinese spying and hacking, US intelligence are increasingly sharing with the Justice Department revelatory information about 
Chinese operations. This has led to a string of recent indictments." ${ }^{31}$ This all-out use of domestic laws to reinforce trade actions is unprecedented. They amount to use of domestic legislation for unintended purposes.

6. Many of the president's trade actions are mystifying in terms of domestic politics. A new Cato Institute study concluded that "recent public opinion polling uniformly reveals that, first, foreign trade and globalization are generally popular, and in fact more popular today than at any point in recent history." " Needless to say, the apparent impact of the US-China trade disputes on the of the US stock market's downturn, China's stock markets, and global growth over the last few months is a warning sign to President Trump. Interestingly, Chinese companies have flocked to Wall Street to list their shares at the highest level since $2014 .^{33}$

7. Significant parts of President Trump's base are being injured by his tariffs, especially farmers who confront retaliatory tariffs on their agricultural exports. ${ }^{34}$ The new Asian trade agreement, the "Comprehensive and Progressive Agreement for Trans-Pacific Partnership" that replaced the Trans-Pacific Partnership (TPP) that President Trump withdrew from, came into effect this January. ${ }^{35}$ This has even more ominous implications for the US trade with Asia.

8. Active and positive engagement with the global economy, not restrictive actions or tariffs harking back to the beginning of the American Republic up through the 1930 s, is essential to global trade and domestic economic development. Even the term 'America First' that President Trump favors was used by isolationists and protectionists in 1930s' America. The policies espoused at that time did not lead to greatness but only global warfare. Positive US engagement with the global economy and international political system is essential to American security today.

9. Commentators have noted that the Trump administration is attempting to utilize economic tools to achieve strategic goals, and this has resulted in or will result in restructuring laws concerning global transactions. A recent well-stated article said: "The increased convergence of economic and security thinking and strategies is likely to lead to a significant restructuring of the laws and institutions that govern international trade and investment.",36

10. Demands for changes in global laws concerning trade and investment are already seen in the US and the EU as they revise their laws concerning foreign investment. Such demand for change is most obviously evidenced by the US demands for change in the WTO. Some of these demands are justifiable, while others are not. A 
multilateral approach to changes is the best approach. Unilateral threats and bullying are not.

In conclusion, domestic US litigation in 2019 may well have a tremendous impact on the US law and the global trading system. Many in the domestic and international trading communities (as well as those in the foreign policy and national security communities) are waiting for the results of this little-known steel litigation. We'll see.

\section{REFERENCES}

1. American Institute for International Steel, et al. v. United States et al. (Court of International Trade \# 18-00152) (Filed June 27, 2018). Complaint, motion for summary judgment and other pleadings 2018, are on the website of the American International Institute for Steel, available at http://www.aiis.org/2018/06/american-institute-for-international-steel-fileslawsuit-challenging-constitutionality-of-section-232-steel-tariffs; available at http://www. aiis.org/2018/10/aiis-seeks-to-end-enforcement-of-section-232-steel-tariffs-with-summaryjudgment-filing (all last visited on Jan. 14, 2019).

2. United States - Certain Measures on Steel and Aluminum Products (By China), WTO Doc. WT/DS544/8 (adopted Oct. 19, 2018), available at https://www.wto.org/english/tratop_e/ dispu_e/cases_e/ds544_e.htm (last visited on Jan. 14, 2019).

3. United States - Certain Measures on Steel and Aluminum Products (By the EU), WTO Doc. WT/DS548/14 (adopted Oct. 19, 2018), available at https://www.wto.org/english/tratop_e/ dispu_e/cases_e/ds548_e.htm (last visited on Jan. 2, 2019).

4. Disputes by Members - United States as Respondent, available at https://www.wto.org/ english/tratop_e/dispu_e/dispu_by_country_e.htm (last visited on Jan. 14, 2019).

5. Supra note 1.

6. G. Thrush, Trump Use of National Security to Impose Tariffs Faces Court Test, N.Y. Times, Dec. 19, 2018, available at https://www.nytimes.com/2018/12/19/us/politics/trump-nationalsecurity-tariffs.html (last visited on Jan. 14, 2019).

7. "More than 90 percent of the Department's cases alleging economic espionage over the past seven years involve China." See US Dept. of Justice, Deputy Attorney General Rod J. Rosenstein Announces Charges against Chinese Hackers (Dec. 20, 2018), available at https:// www.justice.gov/opa/speech/deputy-attorney-general-rod-j-rosenstein-announces-chargesagainst-chinese-hackers (last visited on Jan. 14, 2019).

8. R. Fefer et al., Extraterritorial Application of American Criminal Law: An Abbreviated 
Sketch, RS22497 (Oct. 31, 2016), available at https://fas.org/sgp/crs/misc/R45249.pdf (last visited on Dec. 29, 2018).

9. E.g., Justice against Sponsors of Terrorism Act, Pub.L. 114-222 (enacted 2016), available at https://www.govinfo.gov/content/pkg/PLAW-114publ222/html/PLAW-114publ222.htm (last visited on Jan. 2, 2019).

10. The Case of the S.S. "Lotus" (Fr. v. Turk.), Judgment, 1927 P.C.I.J. (ser. A) No.10, available at http://www.worldcourts.com/pcij/eng/decisions/1927.09.07_lotus.htm (last visited on Jan. 14, 2019).

11. C. Savage, Trump's Push for Trade Win Could Undermine Sanctions Enforcement, N. Y. TimEs, Dec. 12, 2018, available at https:/www.nytimes.com/2018/12/14/us/politics/huaweitrump-china.html (last visited on Jan. 14, 2019).

12. J. Sachs, The US, Not China, is the Real Threat to Rule of Law, Globe \& MaIL, Dec. 12, 2018, available at https://www.theglobeandmail.com/opinion/article-the-us-not-china-isthe-real-threat-to-international-rule-of-law (last visited on Jan. 14, 2019).

13. See Trump Makes Huawei CFO Meng Wanzhou a Bargaining Chip, Fin. Times (Editorial), Dec. 13, 2018, available at https://www.ft.com/content/cccf5fe2-fe1f-11e8-ac0057a2a826423e (last visited on Jan. 14, 2019).

14. U.N. Charter art. 2, para. 4.

15. Vienna Convention on the Law of Treaties, art. 52, available at https://treaties.un.org/doc/ publication/unts/volume\%201155/volume-1155-i-18232-english.pdf (last visited on Jan. 14, 2019).

16. An outstanding Presidential historian has recently written: "The Founders would probably be thunderstruck to discover that the option to start a war of a magnitude they would find inconceivable ... may now rest on the whim of a President." See M. Beschloss, Presidents OF WAR 586 (2018).

17. See generally the official website for the United States Court of International Trade, available at https://www.cit.uscourts.gov (last visited on Jan. 4, 2019).

18. R. Fefer et al., Section 232 Investigations: Overview and Issues for Congress, R45249 (Nov. 21, 2018), available at https://fas.org/sgp/crs/misc/R45249.pdf (last visited on Dec. 29, 2018).

19. W. Mauldin, Court Questions Law that Underpins Trump's Trade Policy, Wall St. J., Dec. 19, 2018, available at https:/www.wsj.com/articles/court-questions-trumps-use-ofnational-security-law-to-impose-tariffs-11545255708 (last visited on Jan. 14, 2019). This case involved the presidential imposition of an arms embargo during the Chaco War in the 1930s.

20. US v. Curtis-Wright Export Corp. 299 U.S. 344; 57 S. Ct. 216 (1936), available at https:// supreme.justia.com/cases/federal/us/299/304 (last visited on Jan. 14, 2019).

21. Youngstown Sheet \& Tube Co. v. Sawyer, 343 U.S. 579 (1952), available at https:// supreme.justia.com/cases/federal/us/343/579 (last visited on Jan. 2, 2019). 
22. FEA v. Algonquin SNG, Inc., 426 U.S. 548 (1976), available at https://supreme.justia.com/ cases/federal/us/426/548 (last visited on Jan. 14, 2019).

23. Yoshida International v. United States (US Customs Court), 526 F.2d 560 (C.C.P.A. 1975), available at https://casetext.com/case/united-states-v-yoshida-intern-inc (last visited on Jan. 14, 2019).

24. G. Thrush, Trump's Use of National Security to Impose Tariffs Face Court Test, N.Y. TIMES, Dec. 19, 2018, available at https:/www.nytimes.com/2018/12/19/us/politics/trumpnational-security-tariffs.html (last visited on Jan. 14, 2019).

25. G. Will, Some Senators are Aiming to Claw Back Trade Power from Trump, Wash. Post, Dec. 16, 2018, available at https://www.washingtonpost.com/opinions/these-three-senatorsare-aiming-to-claw-back-trade-power-from-trump/2018/12/14/5b9e04f8-ff10-11e8-862ab6a6f3ce8199_story.html?utm_term=.118730814495 (last visited on Jan. 14, 2019).

26. C. Owens, Chuck Grassley Wants to Limit Trump's Trade Authority, AXIOS, Dec. 2, 2018, available at https://www.axios.com/chuck-grassley-trump-tariffs-section-232-nationalsecurity-613bb759-acac-4a36-9703-9a2ee1958f28.html (last visited on Jan. 14, 2019).

27. D. Ignatius, America's Overt Payback for China's Covert Espionage, Wash. Post, Nov. 15, 2018, available at https:/www.washingtonpost.com/opinions/global-opinions/americasovert-payback-for-chinas-covert-espionage/2018/11/15/a88d1416-e921-11e8-a9399469f1166f9d_story.html?utm_term=.b907fc9f7c67 (last visited on Jan. 14, 2019).

28. S. Malawer, Confronting Chinese Cyber Espionage with WTO Litigation, 252:120 N.Y.L.J. 4 (Dec. 2014), available at https://www.law.com/newyorklawjournal/almID/1202712784205/ Confronting-Chinese-Economic-Cyber-Espionage-With-WTO-Litigation/?slreturn=201900 03114132\#ixzz3MfIKeTXb (last visited on Jan. 14, 2019).

29. China - Certain Measures Concerning Intellectual Property Rights (By US), WTO Doc. WT/DS542/8, available at https://www.wto.org/english/tratop_e/dispu_e/cases_e/ds542_ e.htm (last visited on Jan. 14, 2019).

30. R. Keagan, The Jungle Grows Back 137 (2018).

31. Ignatius, supra note 27.

32. S. Lincicome, The 'Protectionist Moment' That Wasn't, 72 Free Trade Bull. (CATO Institute) (Nov. 2, 2018), available at https://www.cato.org/publications/free-trade-bulletin/ protectionist-moment-wasnt-american-views-trade-globalization (last visited on Jan. 14, 2019).

33. S. Grocer, Chinese Companies Flocked to US Markets in 2018. The Trade War May Have Had a Role, N. Y. Times, Jan. 3, 2019, available at https://www.nytimes.com/2019/01/02/ business/dealbook/trade-war-china-ipos.html (last visited on Jan. 14, 2019).

34. B. Appelbaum, Their Soybeans Piling Up, Farmers Hope Trade War Ends before Beans Rot, available at https:/www.nytimes.com/2018/11/05/business/soybeans-farmers-tradewar.html (last visited on Jan. 3, 2019).

35. A. Bevege, Pacific Trade Pact Takes Off with Tariffs Cut in Six Nations, Reuters, Dec. 29, 
2018, available at https:/www.reuters.com/article/us-trade-tpp/pacific-trade-pact-takes-offwith-tariffs-cut-in-six-nations-idUSKCN1OT00C (last visited on Jan. 14, 2019).

36. A. Robert et al., The Geoeconomic World Order, LAWFARE (Nov. 19, 2018), available at https://www.lawfareblog.com/geoeconomic-world-order (last visited on Jan. 14, 2019). 